Ann. Parasitol. Hum. Comp., 1993, $68: \mathrm{n}^{\circ} 5 / 6,220-225$.

Mémoire.
Key-words: Plasmodium berghei. Plasmodium falciparum. Haemosporina. Malaria. Rodent. Human. Erythrocytic stages. Exoerythrocytic stages. Sporozoites. Separation. Urografin. Density gradient centrifugation.

Mots-clés : Plasmodium berghei. Plasmodium falciparum. Haemosporina. Malaria. Rongeurs. Humain. Formes érythrocytaires. Formes exoérythrocytaires. Sporozoïtes. Urografine. Centrifugation à gradients de densité.

\title{
PLASMODIUM BERGHEI : THE USE OF DISCONTINUOUS UROGRAFIN DENSITY GRADIENTS FOR THE SEPARATION OF EXOERYTHROCYTIC MALARIA PARASITES
}

\author{
G. FRANÇOIS, I. DESOMBERE, M. WÉRY
}

\begin{abstract}
SUMMARY
Urografin was used in the lower cushion of discontinuous density gradient systems, for the separation of human hepatoma cells (Hep G2) infected with exoerythrocytic $P$. berghei forms from uninfected cells. The hepatoma cells exhibited a rather heterogeneous density distribution, masking the possible density differences between infected and uninfected cells and hindering the efficient separation of both cell types. Purely osmotic damage caused by Urografin on human erythrocytes and hepatoma cells is very limited.
\end{abstract}

On the other hand, the direct toxic effects on $P$. falciparum blood stages and on $P$. berghei exoerythrocytic stages are very pronounced. The growth of the former forms is partially inhibited after a pretreatment, but remains acceptable if the contact with Urografin is relatively short. It is almost completely blocked during permanent incubation. The latter forms are killed after 1 hour of contact with Urografin.

RÉSUMÉ: L'utilisation de gradients de densité discontinue à l'urografine pour la séparation des stades éxoérythrocytaires de Plasmodium berghei.

L'urografine a été utilisée dans la couche inférieure de gradients de densité discontinue, pour la séparation de cellules d'hépatome humain (Hep G2) infectées de formes exoérythrocytaires de $P$. berghei et de cellules non infectées. Des cellules dérivées d'hépatome humain ont suivi une distribution de densités relativement hétérogène, en masquant les différences en densité éventuelles entre des cellules infectées et non infectées, et en gênant donc la séparation efficace des deux types cellulaires. Les dégâts purement osmotiques causés par l'urografine sur les érythrocytes humains et sur les hépatomes sont très limités. D'un autre côté, les effets toxiques immédiats sur les formes érythrocytaires de $P$. falciparum et sur les formes exoérythrocytaires de $P$. berghei sont très prononcés. La croissance de ces premières formes est partiellement inhibée après le prétraitement, mais elle reste acceptable si le contact avec l'urografine est relativement court. Cette croissance est presque complètement inhibée pendant une incubation permanente. Les formes exoérythrocytaires de $P$. berghei sont tuées après 1 heure de contact avec l'urografine.

\section{INTRODUCTION}

Satisfying separation methods are essential for the efficient physiological, biochemical and immunological study of different development stages of parasites. In the case of malaria parasites, many, often successful attemps have been made.

In general, most attention has been focused on the erythrocytic stages of Plasmodium sp. Briefly, many types of continuous and discontinuous gradient centrifugation procedures have been applied to $P$. falciparum, $P$. vivax, $P$. cynomolgi, $P$. knowlesi, $P$. berghei, $P$. chabaudi, $P$. vin-

Laboratorium voor Protozoölogie, Instituut voor Tropische Geneeskunde, Nationalestraat 155, B-2000 Antwerpen, Belgium. Accepté le : 3 juin 1993. ckei, $P$. yoelii and $P$. gallinaceum. The gradients were composed of sucrose (Williamson and Cover, 1966), bovine serum albumin (Rowley et al., 1967), Percoll (Knight and Sinden, 1982; Stanley et al., 1982; Rivadeneira et al., 1983), Ficoll (Eling, 1977; Mrema et al., 1979; Tosta et al., 1980) or metrizamide (Eugui and Allison, 1979).

Gradient centrifugation procedures have been used also for the isolation and concentration of sporozoites : with sucrose for $P$. gallinaceum (Chen and Schneider, 1969), Renografin/bovine serum albumin for $P$. berghei and P. cynomolgi (Krettli et al., 1973), and Medium 199, Renografin and mouse serum (Pacheco et al., 1979), Hypaque (Heidrich et al., 1983), Urografin and Percoll (Pirson, 1982) for $P$. berghei.

Only limited attention has been paid to the isolation, concentration or purification of the other exoerythrocytic 
Plasmodium stages. Most of these efforts have been directed towards merozoites and mature free schizonts from the supernatant medium of infected in vitro cultures, collected by centrifugation. This was the case for $P$. lophurae merozoites obtained from embryonic turkey brain cells and purified on an ion exchange column (Hollingdale and Kilejian, 1979), for $P$. berghei merozoites from Hep G2-A16 cells (Hollingdale et al., 1985) and for free P. berghei schizonts and merozoites from Hep G2 cells (Suhrbier et al., 1989). No successful attempts to separate host cells harbouring exoerythrocytic Plasmodium forms in vitro from uninfected cells have been reported.

One gradient for isolation of sporozoites was composed of Urografin (Pirson, 1982) and the same product has successfully been applied in our laboratory for the separation of blood forms of $P$. falciparum and $P$. berghei (unpublished results). Urografin is a mixture of sodium diatrizoate and methylglucamine diatrizoate. Both components are radiopaque media and are of diagnostic aid as contrast products for urography and angiography. We report here a first attempt to separate human hepatoma cells functioning as host cells for $P$. berghei exoerythrocytic stages from uninfected cells by discontinuous Urografin density gradient centrifugation.

\section{MATERIALS AND METHODS}

The malaria vector Anopheles stephensi was reared in an insectary under standard conditions. Sporozoites for experimental use were prepared from salivary glands as described previously (François et al., 1991).

Human hepatoma cells Hep G2 (London) (Aden et al., 1979) were grown in $25 \mathrm{~cm}^{2}$ sterile culture flasks (Nunc), essentially as described earlier (François et al., 1991). Near confluent monolayers were rinsed with MEM Rega 3 (Gibco), complete with serum, and incubated for 2 hours with a suspension of $P$. berghei sporozoites at $37^{\circ} \mathrm{C}$. After that time, the remainder of the sporozoites was eliminated by rinsing the cultures with medium. The hepatoma cells harbouring exoerythrocytic parasites were harvested after 58 hours with the aid of a $0.25 \%$ trypsin solution (Gibco), washed, centrifuged at $600 \mathrm{~g}$ for $5 \mathrm{~min}$ and resuspended.

Urografin $60 \%$ (Schering AG) was mixed with complete MEM Rega 3 in a series of dilutions. Suspensions containing infected or non-infected Hep G2 cells functioned as the upper layer $(10 \mathrm{ml})$ on top of the Urografin cushion $(10 \mathrm{ml})$ and were spun down at $1,600 \mathrm{~g}$ for $25 \mathrm{~min}$ in a Jouan CR 1000 centrifuge. The density $(\mathrm{g} / \mathrm{ml})$ of each Urografin dilution was determined by weighing 4 samples. Final values were calculated from a linear regression based on the means.

Cells harvested from interphases and pellets were washed in MEM Rega 3, centrifuged at $700 \mathrm{~g}(5 \mathrm{~min})$ and resuspended in $5 \mathrm{ml}$ of medium. Samples were taken in duplicate and counted 2 times in an improved double Neubauer chamber. The morphology of treated hepatoma cells was studied microscopically (Leitz, $500 \times$ ). The viability of the recovered cells was checked by using washed and resuspended cells as inocula for Hep G2 subcultures. Their growth and appearance was monitored during 5 days.

Six-week-old female OF1 mice (IFFA Credo) were injected i.p. with Hep G2 cells containing exoerythrocytic $P$. berghei stages.
Thin smears were made with tail blood, 5 to 12 days after infection. The parasitaemias were determined after methanol fixation. Giemsa staining and counting of at least 10,000 RBC.

$P$. falciparum (FCA-1) was kept in vitro in static (1\% haematocrit) or shaking ( $5 \%$ haematocrit) continuous cultures (Trager and Jensen, 1976). The culture medium was RPMI 1640 (Flow) supplemented with $2 \mathrm{~g} \mathrm{NaHCO}_{3} / 1,0.02 \mathrm{ml}$ gentamicin/l (Merck), $5.94 \mathrm{~g}$ Hepes/1 (BDH), $2 \mathrm{~g} a(\mathrm{D}+)$-glucose/1 and $0.05 \mathrm{~g}$ hypoxanthin $/ 1$ (Sigma). Human plasma $(\mathrm{A}+)$ was present at $10 \%$ and $\mathrm{RBC}(\mathrm{A}+$ or $\mathrm{O}+)$ were donated by laboratory volunteers. The atmosphere in the culture flasks was composed of $5 \% \mathrm{O}_{2}, 5 \%$ $\mathrm{CO}_{2}$ and $90 \% \mathrm{~N}_{2}$ (L'Air Liquide). The static cultures were kept in an incubator (Jouan EB $280 \mathrm{~S}$ ) and the rotating cultures in a conditioned shaker (New Brunswick Scientific G25) at $37^{\circ} \mathrm{C}$. Both types of cultures were subcultured every 3-4 days. All inocula had a parasitaemia of about $1 \%$.

$P$. falciparum infected erythrocytes with known parasitaemia were prepared from in vitro cultures and incubated for 1 hour in Urografin, diluted with complete RPMI $(0.0,25.0,32.5$ and $40.0 \%$ respectively). Samples were taken and the numbers of plasmolysed and unaffected cells were counted in an improved double Neubauer chamber. The suspensions were thoroughly washed in RPMI and incubated for 1 hour in the same medium. The proportion of damaged cells was counted. The parasitaemias were measured again and reduced to $1 \%$ in subcultures with $1 \%$ haematocrit. Final parasitaemias were determined after 4 days of culture.

The growth of $P$. falciparum blood forms was measured after incubating cultures, at $1 \%$ haematocrit and with an initial parasitaemia of $1 \%$, in dilutions containing $4 \mathrm{ml}$ of complete RPMI and $1 \mathrm{ml}$ of $25.0,32.5$ or $40.0 \%$ Urografin (final concentrations: 5.0, 6.5 and $8.0 \%$ resp.). The controls contained only complete RPMI. After 3 days of incubation thin smears were made and the parasitaemias were determined.

Wherever necessary, the results were evaluated by one-way analysis of variance (ANOVA). All calculations were made with the aid of the Statgraphics program (PLUS WARE, STSC).

\section{RESULTS}

The relative distribution of non-infected Hep G2 cells is presented in Figure 1. All cells were found in the pellets when 15.0-25.0 \% Urografin was used. All but a few cells were found in the interphase at concentrations between 32.5 and $45.0 \%$. Between 25.0 and $32.5 \%$ Urografin, the cells rather abruptly switched from pellet to interphase. The density of non-infected Hep G2 cells corresponded with a Urografin $60 \%$ : MEM Rega 3 mixture between (25.0:75.0) $(1.044 \mathrm{~g} / \mathrm{ml})$ and $(32.5: 67.5)(1.065 \mathrm{~g} / \mathrm{ml})$. The theoretical value with $50 \%$ of the cells in the pellet and $50 \%$ in the interphase was reached at $31.0 \%$ Urografin $(1.061 \mathrm{~g} / \mathrm{ml})$. This places the Hep G2 cells in the same density range as rat liver parenchymal cells (Kreamer et al., 1986).

The viability of the hepatoma cells recovered from interphase and pellet was strongly dependent on the composition of the gradient (data not shown). At least part of the cells harvested from the interphases were proved to be viable in vitro when the cushions contained between 25.0 and $45.0 \%$ Urographin. In the pellets on the other hand, 


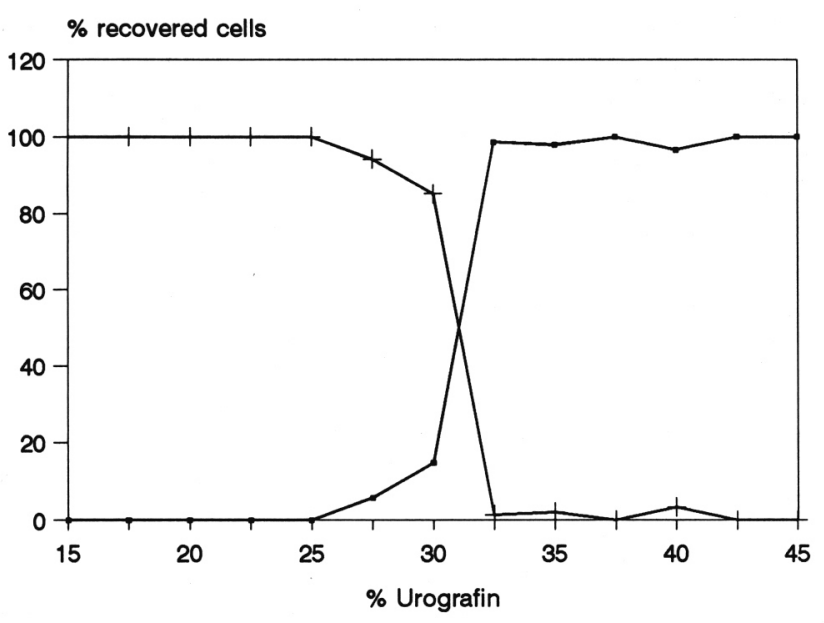

Fig. 1. - Number of hepatoma cells in interphase and pellet after discontinuous density gradient centrifugation. Upper layer: Hep G2 (London) cell suspension in complete MEM Rega 3. Lower layer: mixture Urografin $60 \%$ : complete MEM Rega 3. Centrifugation at $1,600 \mathrm{~g}$ for $25 \mathrm{~min}$. Results expressed as percentages of total number of recovered cells. Mean values $(n=4) \pm$ s.e.m.; $\square=$ interphase; $+=$ pellet.

viable cells were present when cushions were used with Urografin concentrations between 15.0 and $45.0 \%$, although the cultures derived from the 32.5-45.0 \% gradients exhibited only a very limited growth. In general, these statements correspond well with the data shown in Figure 1. In both series of cultures two points were remarkable: the presence of rather large numbers of non-adherent cells, even in confluent or less than confluent cultures, and the abnormal morphological appearance of adherent cells.

Two Urografin concentrations (25.0 and $32.5 \%$ ) were selected, in an attempt to separate $P$. berghei infected Hep G2 cells from non-infected cells. The parasitaemias measured in mice injected with suspensions derived from interphases and pellets are shown in Table I. At $25 \%$, most of the exoerythrocytic parasites too were present in the pellet and more or less the reverse could be said about the results obtained with $32.5 \%$ Urografin.

Direct effects of Urografin in vitro were observed by incubating trypsinized and washed $25 \mathrm{~cm}^{2}$ Hep G2 monolayers in 25.0, 32.5 and $40.0 \%$ Urografin resp., for 1 hour at room temperature. Microscopic observation revealed the sticky appearance of the cells and a low degree of plasmolysis, most pronounced at $40.0 \%$. Plasmolysis was not manifested by severe cell shrinking, but only by crenating of the plasmalemma. The vast majority of the cells remained intact after deplasmolysis and only a very small part had undergone damage. The membranes of the latter cells exhibited openings and tears, with one or more protrusions of cytoplasm into the medium. Ghost membranes
TABLE I. - Parasitaemias in OF1 mice, 12 days after intraperitoneal injection with Hep G2 (London) suspensions derived from interphases and pellets from discontinuous Urografin density gradients. Hepatoma cell cultures infected with Plasmodium berghei sporozoites 72 hours before gradient centrifugation. Centrifugation at 1,600 g for $25 \mathrm{~min}$. Each hepatoma cell suspension is a pool of 2 trypsinized $25 \mathrm{~cm}^{2}$ monolayers.

\begin{tabular}{cccc}
\hline \& Urografin & \multicolumn{2}{c}{$\begin{array}{c}\text { Parasitaemia }(\xi) \\
\text { pellet }\end{array}$} & highest value \\
\hline 25.0 & 0.80 & 3.30 & pellet \\
& 0.00 & 0.02 & pellet \\
& 7.50 & 25.00 & pellet \\
& 0.00 & 2.30 & pellet \\
& & & \\
32.5 & 3.70 & 0.00 & interphase \\
& 1.00 & 0.00 & interphase \\
& 2.60 & 0.60 & interphase \\
& 2.10 & 1.40 & interphase \\
& & & \\
\hline
\end{tabular}

TABlE II. - Parasitaemias in OFI mice on days 5, 8 and 12 after intraperitoneal injection with Hep G2 (London) cells containing Plasmodium berghei exoerythrocytic stages, previously treated for 1 hour in vitro with Urografin. Mean values \pm s.e.m. $(\mathrm{n}=4)$.

\begin{tabular}{|c|c|c|c|}
\hline \multirow{3}{*}{$\frac{\text { Urografin }}{0.0}$} & \multicolumn{3}{|c|}{ Parasitaemia (8) } \\
\hline & day 5 & day 8 & day 12 \\
\hline & $0.00 \pm 0.00$ & $0.04 \pm 0.02$ & $3.58 \pm 0.14$ \\
\hline 25.0 & $0.00 \pm 0.00$ & $0.00 \pm 0.00$ & $0.00 \pm 0.00$ \\
\hline 32.5 & $0.00 \pm 0.00$ & $0.00 \pm 0.00$ & $0.00 \pm 0.00$ \\
\hline 40.0 & $0.00 \pm 0.00$ & $0.00 \pm 0.00$ & $0.00 \pm 0.00$ \\
\hline
\end{tabular}

were seen as well. These effects were visible at 25.0 and $32.5 \%$ Urografin, and more clearly at $40.0 \%$.

The influence of a Urografin treatment of human hepatoma cells harbouring exoerythrocytic forms of $P$. berghei on the subsequent in vivo development of the parasites is represented in Table II. The control mice developed a normal parasitaemia pattern and became positive between days 5 and 8 . The number of parasites rose sharply between days 8 and 12. The mice which received treated hepatoma cells remained negative, even after 12 days. This was true for all concentrations used.

The effects of Urografin on erythrocytes in vitro were very different and are given in Table III. Incubation during 1 hour in $25.0,32.5$ or $40.0 \%$ of Urografin provoked a high proportion of plasmolysed erythrocytes in all cases, ranging between 84 and $97 \%$. Plasmolysis was reflected by shrinking of the cell content, resulting in a pronounced crenated appearance of the plasmalemma. Membrane damage caused by subsequent deplasmolysis was extremely limited. Empty ghosts were only very seldom observed.

The growth of $P$. falciparum blood stages, when pre- 
TABLE III. - Numbers of erythrocytes plasmolysed after Urografin treatment and damaged after deplasmolysis in complete RPMI medium. Initial parasitaemia $=10.41 \%$. Incubation for 1 hour in various Urografin concentrations, followed by 1 hour incubation in complete RPMI. Mean values \pm s.e.m. $(\mathrm{n}=4)$. Countings in an improved double Neubauer chamber. $P=$ number of plasmolysed cells; $G=$ number of ghosts after deplasmolysis; $T=$ total number of cells.

\begin{tabular}{|c|c|c|c|c|}
\hline \&rografin & $\mathrm{P} / \mathrm{T}$ & Mean of $100 \mathrm{P} / \mathrm{T}$ & $\underline{G / T}$ & Mean of $100 \mathrm{G} / \mathrm{T}$ \\
\hline \multirow[t]{4}{*}{0.0} & $0 / 99$ & $0.00 \pm 0.00$ & $0 / 285$ & $0.00 \pm 0.00$ \\
\hline & $0 / 103$ & & $0 / 264$ & \\
\hline & $0 / 126$ & & $0 / 292$ & \\
\hline & $0 / 87$ & & $0 / 273$ & \\
\hline \multirow[t]{4}{*}{25.0} & $74 / 86$ & $84.06 \pm 0.98$ & $1 / 272$ & $0.18 \pm 0.10$ \\
\hline & $36 / 43$ & & $0 / 290$ & \\
\hline & $44 / 54$ & & $1 / 285$ & \\
\hline & $68 / 80$ & & $0 / 286$ & \\
\hline \multirow[t]{4}{*}{32.5} & $143 / 153$ & $94.35 \pm 0.77$ & $1 / 272$ & $0.18 \pm 0.11$ \\
\hline & $134 / 142$ & & $0 / 273$ & \\
\hline & $83 / 86$ & & $1 / 273$ & \\
\hline & $94 / 101$ & & $0 / 279$ & \\
\hline \multirow[t]{4}{*}{40.0} & $139 / 141$ & $96.58 \pm 0.69$ & $0 / 266$ & $0.27 \pm 0.09$ \\
\hline & $104 / 109$ & & $1 / 321$ & \\
\hline & $96 / 100$ & & $1 / 239$ & \\
\hline & $131 / 136$ & & $1 / 286$ & \\
\hline
\end{tabular}

TABLE IV. - Growth of P. falciparum in vitro during 3 days, in the presence of Urografin. Initial parasitaemia $=1 \%$. The final concentrations $(5.0,6.5$ and $8.0 \%$ resp.) correspond with $1 \mathrm{ml}$ of resp. 25.0, 32.5 and $40.0 \%$ of Urografin on a total culture volume of $5 \mathrm{ml}$. Mean values \pm s.e.m. $(\mathrm{n}=4)$. Significance levels of the difference between treatments and controls.

\begin{tabular}{ccc}
\hline Urografin 8 & Parasitaemia $(\xi)$ & Significance level \\
\hline 0.0 & $2.18 \pm 0.38$ & - \\
25.0 & $0.24 \pm 0.05$ & 0.0023 \\
32.5 & $0.01 \pm 0.00$ & 0.0013 \\
40.0 & $0.00 \pm 0.00$ & 0.0013 \\
\hline
\end{tabular}

treated with Urografin in the same way as the uninfected erythrocytes, was dramatically influenced as well (data not shown). All tested concentrations (25.0-40.0 \%) reduced the parasite growth significantly and proportionally. In none of the cases was the inhibition sufficient to stop the growth completely.

Table IV shows the growth of $P$. falciparum blood forms in the presence of Urografin. All concentrations were totally inhibitory and most of the inoculum cells were even destroyed. After incubation with $40 \%$ Urografin, no more parasites could be detected.

\section{DISCUSSION}

Urografin was proved to be a very useful compound for density gradient centrifugation of $\boldsymbol{P}$. berghei and $\boldsymbol{P}$. falciparum erythrocytic forms. From both species, viable schizonts have been obtained, producing merozoites capable of re-infection of fresh red blood cells in vivo ( $P$. berghei) or in vitro ( $P$. falciparum) (unpublished results). The lower cushion was composed of Urografin: complete RPMI in a ratio 5:7, or $41.7 \%$ Urografin. The proportions of viable parasites before and after centrifugation were not checked. Triphasic Urografin density gradients have been used for the mass preparation of $P$. berghei sporozoites as well (Dengler, 1978). The method yielded a very high number of sporozoites compared with a harvest after dissection of salivary glands of Anopheles stephensi (29,885 versus 16,208 sporozoites/mosquito). However, only part of the sporozoites obtained from gradient interphases was infectious (Dengler, 1978).

In the other cases where Urografin or its compounds were used in linear (Krettli et al., 1973) or biphasic (Heidrich et al., 1983) gradients for the separation of different stages of malaria parasites, no negative effects on morphology, viability or infectivity have been reported. Moreover, the general use of these substances for diagnostic purposes (Morrow, 1980; Budavari, 1989) allows us to suppose that their application to biological material is safe. The manufacturer confirms their relatively good tolerance by patients. Their use as components of layering solutions for the production of uncontaminated platelet suspensions, functionally viable human, rat, rabbit and goat lymphocytes (Perper et al., 1968), and viable human polymorphonuclear leukocytes (Bignold and Ferrante, 1987) has been reported.

Centrifugation of uninfected hepatoma cell suspensions layered upon Urografin cushions revealed the existence of a heterogeneous cell population. Theoretically, the suspension was equally distributed between interphase and pellet at a Urografin concentration of $31.0 \%$, corresponding with a cell density of $1.061 \mathrm{~g} / \mathrm{ml}$. However, in a rather broad range of adjacent concentrations (25.0-32.5\%) $(1.044-1.065 \mathrm{~g} / \mathrm{ml})$ the cells continued to appear in both phases, and between $27.1 \%(1.050 \mathrm{~g} / \mathrm{ml})$ and $32.4 \%$ $(1.064 \mathrm{~g} / \mathrm{ml})$ they were represented for more than $5 \%$ in the " wrong " phase. Between 25.0-27.1\% and 32.4-42.5\% $(1.044-1.050 \mathrm{~g} / \mathrm{ml}$ and $1.064-1.093 \mathrm{~g} / \mathrm{ml}), 0$ to $5 \%$ of the total number was found in the "wrong " phase. This lack of homogeneity causes problems when efforts are made to separate infected from uninfected cells. Indeed, the differences in density between infected and uninfected cells are expected to be relatively small and could be completely masked when host cells are used with the described heterogeneity.

At least part of the cells recovered from the two phases were viable. Even when very low numbers of cells were present (interphase at $25.0 \%$ and pellet at $37.5 \%$ Urografin), in vitro cultures could be initiated. Especially in the latter cases, most of the cells must have been in good condition, otherwise the rather low plating efficiency of 
the Hep G2 cells (François et al., 1991) would not have permitted further growth. These results support the point of view that Urografin is not directly poisonous for mammalian cells.

A practical draw-back of the use of Urografin is its stickiness which made it very difficult to wash from the cell surface. It was the possible cause of the presence of so many non-adherent cells and of the somewhat altered morphology of the adherent cells. The general growth pattern of the adherent cells however, did not seem to be influenced by this phenomenon.

The results of trials to separate Hep G2 cells containing $P$. berghei exoerythrocytic stages from uninfected cells were checked by injection of the cells recovered from both phases into OF1 mice, permitting the parasites to develop further in vivo. At $25 \%$ Urografin in the lower cushion, cells infective for mice were apparently found in both fractions, with a very pronounced representation in the pellets and only a minority in the interphases (Table III), thus reflecting about the same distribution as the uninfected cells (Fig. 1). The same can, mutatis mutandis, be said about the observations at $32.5 \%$ Urografin in the lower gradient layer. Again, these findings lead to the conclusion that the density differences between uninfected cells and immature $P$. berghei containing cells are neglectable or at least completely masked by the wide natural distribution range of the uninfected human hepatoma cells.

Although the direct osmotic effects of Urografin on Hep G2 cells were very limited when concentrations between 25.0 and $40.0 \%$ were used, the data shown in Table II reveal that incubation for 1 hour in Urografin solutions was sufficient to kill all exoerythrocytic $P$. berghei forms in vitro. Alternatively, it could have killed the full-grown schizonts in vitro and prevented the further development of the immature exoerythrocytic forms in vivo, which is possible in standard conditions (François et al., 1991). the lethal or blocking effects of Urografin were already total at $25.0 \%$. This is in contrast with the data from Table $I$, where the contact time with Urografin was shorter. At first sight, these statements could be explained by purely osmotic effects. However, the proportion of $P$. berghei infected Hep G2 cells was in the range of $1 \%$ of the total number of cells (François et al., 1991), while the proportion of damaged cells was much smaller. Moreover, it has not been proved that $\boldsymbol{P}$. berghei infected cells are osmotically more vulnerable than uninfected cells. These arguments make it improbable that osmotic shock was the cause of the inhibition of $P$. berghei in vitro. Direct and selective toxicity seems to be a more plausible explanation.

For reasons of comparison, the osmotic effects caused by Urografin were examined in uninfected human erythrocytes as well. Already at the lowest concentrations many cells were clearly plasmolysed and at the highest applied concentration almost all cells were affected. The measured diameters (mean values \pm s.e.m.; $\mathrm{n}=40$ ) for the control were $(7.00 \pm 0.07) \mu \mathrm{m}$ and for $32.5 \%$ Urografin (6.05 \pm 0.16$) \mu \mathrm{m}$, which means a shrinking of the cells corresponding with a decrease in diameter of $13.57 \%$ and an estimated volume loss of about $25 \%$, comparable with the results found for Hypaque-Ficoll gradients (Bignold and Ferrante, 1987). The proportion of irreversibly damaged cells after deplasmolysis in the regular medium was extremely low in all cases and never exceeded $0.30 \%$ of the total number of observed cells. Slightly or moderately damaged cells were never seen. This corresponds well with the observations made on hepatoma cells.

In contrast to the effects caused on mammalian cells, the influence of Urografin on $P$. falciparum parasites in vitro was very dramatic. Both pretreatment and permanent incubation caused growth inhibition, in the latter case even accompanied with destruction of the inoculum cells. Again, selective toxic effects with unknown mechanism are probable.

Concluding, the inherent wide density distribution range of the host cells prevents an efficient purification of $P$. berghei infected hepatoma cells with centrifugation methods. Besides, in view at the inhibitory effect of Urografin on parasite growth, contact or incubation times should be limited.

Acknowledgments. - The authors gratefully acknowledge the excellent technical assistance of Mrs. A. CORREwYN, Mr. L. HENDRIX, Mr. G. TIMPERMAN and Mrs. C. VAN Overmeir. Furthermore, they thank Dr. R. SindEN (Imperial College, London) for kindly supplying the Hep G2 (London) cell line.

\section{REFERENCES}

Aden D. P., Fogel A., Plotkin S., Damjanov I., Knowles B. B. : Controlled synthesis of $\mathrm{HBsAg}$ in a differentiated human liver carcinoma-derived cell line. Nature, 1979, 282, 615-616.

Bignold L. P., Ferrante A. : Mechanism of separation of polymorphonuclear leukocytes from whole blood by the one-step Hypaque-Ficoll method. J. Immunol. Meth., 1987, 96, 29-33.

Budavari S. (Ed.) : The Merck Index. Eleventh Edition, 1989. Merck \& CO., Inc. Rahway, New Jersey.

Chen D. H., Schneider I. : Mass isolation of malaria sporozoites from mosquitoes by density gradient centrifugation. Proc. Soc. Exp. Biol. Med., 1969, 130, 1318-1321.

Dengler M. : Scheiding en zuivering van Plasmodium berghei sporozoïeten door densiteitsgradiënt, 1978. Dissertation Hoger Technisch Instituut Don Bosco, Hoboken, Belgium.

Eling W. : Ficoll fractionation for the separation of parasitized erythrocytes from malaria infected blood. Bull. WHO, 1977, 55, $105-114$.

Eugui E. M., Allison A. C. : Separation of erythrocytes infected with murine malaria parasites in metrizamide gradients. Parasitol., 1979, 79, 267-275.

François G., Desombere I., Wéry M. : Plasmodium berghei: Susceptibility and growth characteristics of hepatoma cells as hosts for malaria schizonts. Ann. Parasitol. Hum. Comp., 1991, 66, 155-165. 
Heidrich H. G., Danforth H. D., Leef J. L., Beaudoin R. L. : Free-flow electrophoretic separation of Plasmodium berghei sporozoites. J. Parasitol., 1983, 69, 360-367.

Hollingdale M. R., Kilejian A. : Purification of Plasmodium lophurae exoerythrocytic merozoites by an ion exchange column. J. Protozool., 1979, 26, 616-619.

Hollingdale M. R., Leland P., Sigler C. I. : In vitro cultivation of the exoerythrocytic stage of Plasmodium berghei in irradiated hepatoma cells. Am. J. Trop. Med. Hyg., 1985, 34, 21-23.

Knight A., Sinden R. E. : The purification of gametocytes of Plasmodium falciparum and $P$. yoelii nigeriensis by colloidal silica (Percoll) gradient centrifugation. Trans. Roy. Soc. Trop. Med. Hyg., 1982, 76, 503-509.

Kreamer B.-L., Staecker J. L., Sawada N., Sattler G. L., Hsia M. T. S., Pitot H. C. : Use of a low-speed, iso-density Percoll centrifugation method to increase the viability of isolated rat hepatocyte preparations. In Vitro Cellul. Develop. Biol., 1986, 22, 201-210.

Krettli A., Chen D. H., Nussenzweig R. S. : Immunogenicity and infectivity of sporozoites of mammalian malaria isolated by density-gradient centrifugation. J. Protozool., 1973, 20, 662-665.

Morrow J. S. : Reno-M-DIP $30 \%$ and Renografin-60 for use in contrast enhanced body computed tomography: a multicenter study. Curr. Therap. Res., 1980, 27, 229-238.

Mrema J. E., Campbell G. H., Miranda R., Jaramillo A. L., Rieckmann K. H. : Concentration and separation of erythrocytes infected with Plasmodium falciparum by gradient centrifugation. Bull. WHO, 1979, 57, 133-138.

Pacheco N. D., Strome C. P. A., Mitchell F., Bawden M. P., Beaudoin R. L. : Rapid, large-scale isolation of Plasmodium berghei sporozoites from infected mosquitoes. J. Parasitol., 1979, $65,414-417$.
Perper R. J., Zee T. W., Mickelson M. M. : Purification of lymphocytes and platelets by gradient centrifugation. $J$. Lab. Clin. Med., 1968, 72, 842-848.

Pirson P. : Culture of the exoerythrocytic liver stages of Plasmodium berghei sporozoites in rat hepatocytes. Trans. Roy. Soc. Trop. Med. Hyg., 1982, 76, 422

Rivadeneira E. M., Wasserman M., Espinal C. T. : Separation and concentration of schizonts of Plasmodium falciparum by Percoll gradients. J. Protozool., 1983, 30, 367-370.

Rowley P. T., Siddiqui W. A., Geiman Q. M. : Separation of malarial parasites according to age by density gradient centrifugation. J. Lab. Clin. Med., 1967, 70, 933-937.

Stanley H. A., Langreth S. G., Reese R. T., Trager W. : Plasmodium falciparum merozoites: Isolation by density gradient centrifugation using Percoll and antigenic analysis. J. Parasitol., 1982, 68, 1059-1067.

Suhrbier A., Wiser M. F., Winger L., Harte P., Newton M. F., Hodivala K. J., Nicholas J., Sinden R. E. : Contrasts in antigen expression in the erythrocytic and exoerythrocytic stages of rodent malaria. Parasitol., 1989, 99, 165-170.

Tosta C. E., Sedegah M., Henderson D. C., Wedderburn N. : Plasmodium yoelli and Plasmodium berghei: Isolation of infected erythrocytes from blood by colloidal silica gradient centrifugation. Exp. parasitol., 1980, 50, 7-15.

Trager W., Jensen J. B. : Human malaria parasites in continuous culture. Science, 1976, 193, 673-675.

Williamson J., Cover B. : Separation of blood-cell-free trypanosomes and malaria parasites on a sucrose gradient. Trans. Roy. Soc. Trop. Med. Hyg., 1966, 60, 425-427. 